\title{
PEMBUATAN SEDIAAN TEH CELUP DAUN SALAM (Syzygium polyanthum) DENGAN PENAMBAHAN RIMPANG JAHE MERAH (Zingiber officinale Rosc. Var. Rubrum) UNTUK KESEHATAN
}

\author{
Rizki Eka Septiwi' ${ }^{1}$ Dewi Ratnasari2*, Reti Puji Handayani ${ }^{3}$ \\ 1,2,3Sekolah Tinggi Ilmu Kesehatan Holistik
}

*Korespondensi: Jl. Veteran No. 272 Ciseureuh Purwakarta, Email: dewiratnasari@stikesholistic.ac.id

\begin{abstract}
ABSTRAK
Tujuan: Penelitian ini bertujuan untuk membuat sediaan teh celup daun salam (Syzygium polyanthum) dengan rimpang jahe merah (Zingiber officinale Rosc. Var. Rubrum) untuk mengurangi kadar asam urat yang mudah dan praktis dikonsumsi masyarakat.

Metode: Penelitian ini menggunakan metode penelitian tindakan (action research) menggunakan instrumen penelitian berupa lembar wawancara, lembar observasi dan angket uji kesukaan. Sediaan dibuat dengan perbandingan komposisi antara daun salam : jahe merah (2,5:1, 2,5:1,5, dan 2,5:2).

Hasil: Menunjukkan susut pengeringan daun salam sebanyak 3,2\% dan jahe merah 5\% hal ini sesuai dengan persyaratan simplisia yaitu kadar air kurang dari $10 \%$. Dilihat secara organoleptis sediaan teh celup daun salam tahan dan stabil selama 3 minggu penyimpanan dengan proporsi formula yang paling disukai responden adalah formula 3 dengan penambahan jahe merah sebanyak 2 gram adalah $96,67 \%$.

Simpulan: Sediaan teh celup yang disukai oleh masyarakat yaitu formula ketiga dengan penambahan jahe merah 2 gram dan sediaan stabil dalam penyimpanan selama 3 minggu pada suhu kamar.
\end{abstract}

Kata kunci: Daun salam (Syzygium polyanthum), Jahe merah (Zingiber officinale Rosc.Var. Rubrum), Teh Celup

ABSTRACT
Objective: This study aims to make a preparation of tea bags of bay leaves (Syzygium polyanthum) with the rhizome of red ginger (Zingiber officinale Rosc. Var. Rubrum) to reduce uric acid levels easy and is practically consumed by the public.

Methods: This research uses action research method to use research instrument in the form of interview sheet, observation sheet and questionnaire test preferences. Dosage is made by comparison between the composition of leaves : red ginger (to 2.5:1, 2,5:1,5 and 2,5:2).

Results: The result showed shrinkage of drying of bay leaves as much as $3.2 \%$ and ginger red 5\% this is in accordance with the requirements of the crude drug i.e. a water content of less than 10\%. Viewed in organoleptic dosage tea bag leaves resistant and stable during 3 weeks of storage with the proportions of the formula the most preferred respondents is a formula 3 with the addition of red ginger as much as 2 grams is $96,67 \%$.

Conclusion: The Preparation of tea bag favored by the public, namely the formula of the third with the addition of red ginger 2 grams and the dosage is stable in storage for 3 weeks at room temperature.

Key words: Chinese petai leaf extract gel, Aloe vera as a base gel, Wound

\section{PENDAHULUAN}

Pada tahun 2013 prevalensi penyakit sendi (asam urat) sebesar 11,9\%, dan sebesar $81 \%$ penderita asam urat di Indonesia hanya $24 \%$ yang pergi kedokter dan $71 \%$ cenderung mengkonsumsi obatobatan pereda nyeri yang dijual secara bebas [1]. Sejak jaman Yunani Kuno penyakit radang sendi dikenal dengan penyakit "Gout" atau "Pirai" selain itu dikenal juga sebagai penyakit orang kaya (gout arthritis) merupakan suatu penyakit yang diakibatkan karena penimbunan kristal monosodium urat di dalam darah 
yang menimbulkan gangguan seperti rasa nyeri didaerah persendian. Asam urat merupakan hasil metabolisme akhir dari purin yaitu komponen asam nukleat yang terdapat dalam inti sel tubuh. Secara alamiah purin terdapat dalam tubuh dan dijumpai pada makanan dari sel hidup yaitu makanan yang berasal dari nabati maupun hewani. Asam urat adalah asam yang berbentuk kristal. Penumpukan kristal didaerah persendian diakibatkan kandungan purinnya dapat meningkatkan kadar asam urat dalam darah antara 0,5$0,75 \mathrm{~g} / \mathrm{ml}$ purin yang dikonsumsi. Konsumsi makanan (digoreng, santan, margarin atau mentega) dan buah-buahan (durian dan alpukat) yang mengandung lemak tinggi juga berpengaruh terhadap pengeluaran asam urat [2].

Masyarakat Indonesia sudah mulai khawatir dengan efek samping yang ditimbulkan dari penggunaan obat-obatan yang terbuat dari bahan sintetis, sehingga banyak masyarakat yang beralih menggunakan obat tradisional. Daun salam (Syzygium polyanthum Wight) merupakan salah satu tanaman yang dapat digunakan sebagai obat asam urat. Masyarakat Indonesia biasa memanfaatkan daun salam (Syzygium polyanthum Wight) sebagai pelengkap bumbu dapur, karena daun salam memiliki aroma yang wangi dan segar. Daun salam memiliki kandungan senyawa kimia seperti: tanin, flavonoid dan minyak atsiri. Secara empiris daun salam sudah banyak digunakan oleh masyarakat dengan pengolahan yang sederhana yaitu dengan membuat rebusan dari daun salam dan minuman fungsional [3].

Mengkonsumsi air rebusan daun salam dapat menurunkan kadar asam urat, karena flavanoid yang terkandung dalam daun salam [4]. Pemberian air rebusan daun (Syzygium polyanthum) mampu menurunkan hiperurisemia (kadar asam urat) dengan nilai signifikansi 0,009 (p $<0,05)$. Pada saat pre-test, tingkat rata-rata asam urat mencapai $7,279 \mathrm{mg} / \mathrm{dl}$, dan setelah perawatan, asam menurun menjadi $6,76 \mathrm{mg} / \mathrm{dl}[5]$.

Kadar asam urat, selain menggunakan daun salam ternyata dapat juga diturunkan oleh bahan alami lainnya yaitu jahe merah. Ekstrak etanol jahe merah (Zingiber officinale Var. Amarum) pada konsentrasi $0,6 \% \mathrm{~b} / \mathrm{v}$ memiliki kemampuan paling baik untuk menurunkan kadar asam urat pada hewan uji kelinci serta 6-gingerol merupakan senyawa bioaktif yang diisolasi dari ekstrak etanol jahe merah [6].

Pembuatan sediaan dari daun salam yang pernah diuji meliputi sediaan rebusan [4], infusa [7] dan minuman fungsional [8] akan tetapi sediaan tersebut tidak menggunakan perasa alami. Sehingga penelitian saat ini yang akan dilakukan yaitu membuat sediaan teh celup dengan penambahan jahe merah yang memiliki kandungan oleoresin sebagai perasa alami untuk menutupi rasa hambar yang dihasilkan oleh daun salam menggunakan metode pengeringan dengan alat (oven). Metode pengovenan dianggap lebih menguntungkan karena terjadi pengurangan kadar air dalam jumlah besar dalam waktu yang singkat [9].

\section{METODE PENELITIAN}

Penelitian ini menggunakan metode penelitian tindakan (Action Research). Penelitian tindakan mengacu pada proses yang berganti secara terus menerus antara penyelidikan dan tindakan antara praktik dan berpikir inovatif [10]. Penelitian tindakan yang dilakukan oleh peneliti yaitu penggunaan daun salam pada pembuatan sediaan teh celup dengan cara mengkombinasikan formula jahe merah

\section{HASIL PENELITIAN \\ Hasil Pembuatan Teh Celup Daun Salam Dengan Rimpang Jahe Merah Yang Dapat Digunakan Untuk Mengurangi Kadar Asam Urat.}

Proses pembuatan teh celup ini dilakukan di Laboratorium Galenika STIKes Holistik Purwakarta pada bulan Mei sampai Agustus 2019. Bahan yang digunakan dalam pembuatan teh celup yaitu daun salam dan rimpang jahe merah. Daun salam (Syzygium polyanthum) yang digunakan diperoleh langsung dari daerah pasar Cikampek, Karawang. Bagian yang digunakan adalah daun yang muda dan tua sedangkan untuk 
rimpang jahe merah diperoleh dari salah satu penjual dipasar Cikampek, Karawang dan hanya sebagai bahan tambahan (perasa alami). Tahap selanjutnya kedua bahan tersebut ditimbang kemudian dicuci bersih dengan air mengalir lalu diangin-angin dan dipotong-potong.

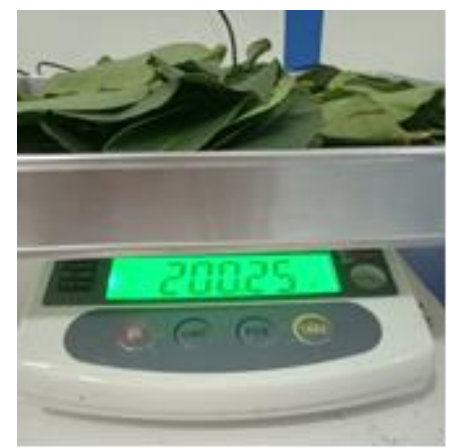

\section{Gambar 1. Proses Penimbangan (Dokumen Pribadi)}

Kedua bahan tersebut dijadikan pengovenan yang dilakukan selama 4 jam sebagai bahan simplisia dengan cara dengan suhu $55^{\circ} \mathrm{C}$.

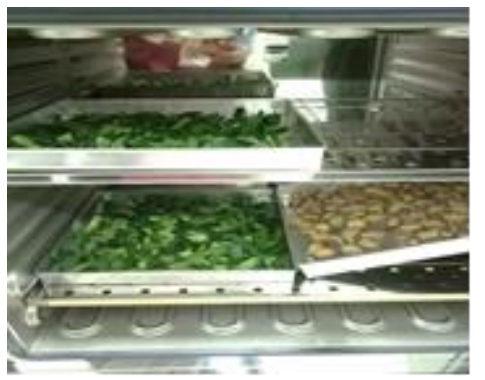

Gambar 2. Proses Pengovenan Daun Salam dan Jahe Merah Segar (Dokumen Pribadi)

Setelah kedua bahan tersebut menjadi simplisia, untuk mengetahui bahan yang digunakan telah memenuhi persyaratan simplisia yang baik maka perlu dilakukan uji susut pengeringan. Hal ini dilakukan untuk mengetahui kadar air yang terkandung didalam bahan tersebut.

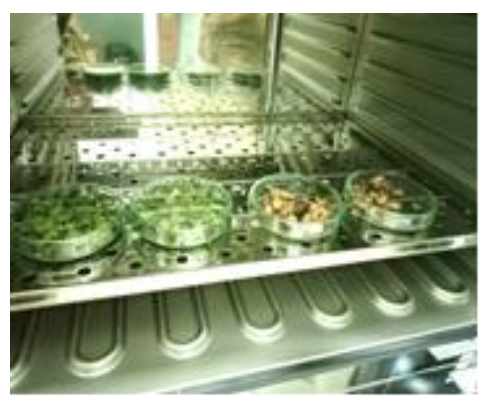

Gambar 3. Susut Pengeringan Simpisia Daun Salam dan Jahe Merah (Dokumen Pribadi)

\section{Hasil Susut Pengeringan}

Tabel 1. Hasil Susut Pengeringan Simplisia Daun Salamdan Jahe Merah

\begin{tabular}{|c|c|c|}
\hline \multicolumn{3}{|c|}{ Sampel (Gram) } \\
\hline & A & B \\
\hline Berat cawan kosong & $102,20 \mathrm{gr}$ & $99,44 \mathrm{gr}$ \\
\hline Berat cawan + simplisia & $107,20 \mathrm{gr}$ & $104,44 \mathrm{gr}$ \\
\hline
\end{tabular}




\begin{tabular}{|c|c|c|} 
Berat sampel & $5,00 \mathrm{gr}$ & $5,00 \mathrm{gr}$ \\
\hline Penimbangan 1 & $107,10 \mathrm{gr}$ & $104,28 \mathrm{gr}$ \\
\hline Penimbangan 2 & $107,05 \mathrm{gr}$ & $104,22 \mathrm{gr}$ \\
\hline Penimbangan 3 & $107,04 \mathrm{gr}$ & $104,19 \mathrm{gr}$ \\
\hline Persentase hasil susut pengeringan & $3,2 \%$ & $5 \%$ \\
\hline
\end{tabular}

Pada Tabel 1 menunjukan hasil susut pengeringan simplisia daun salam dan jahe merah dilakukan dengan menggunakan 2 sampel, dimana sampel pertama untuk simplisia daun salam (A) dan sampel kedua untuk simplisia jahe merah (B), berat dari setiap masing-masing sampel sebanyak 5 gram. Susut pengeringan dilakukan dengan cara menimbang sampel sebanyak 5 gram kemudian dikeringkan menggunakan oven dengan suhu $105^{\circ} \mathrm{C}$ selama 30 menit, kemudian dimasukan kedalam desikator selama 30 menit lalu ditimbang. Proses tersebut dilakukan sebanyak 3 kali hingga didapatkan berat konstan.

Dalam penelitian ini pembuatan teh celup mengadaptasi penelitian (Aryanti, 2007) dengan mengkombinasikan formula jahe merah, masing-masing formulasi dibuat dengan 3 (tiga) sampel untuk diuji pada kondisi penyimpanan yang sama dengan suhu $15^{\circ}-25^{\circ} \mathrm{C}$ (suhu kamar).

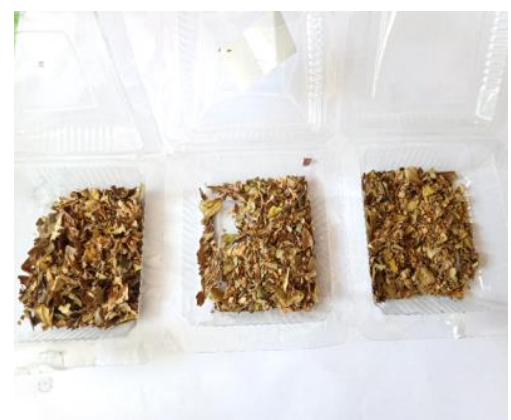

\section{Gambar 4. Proses Pencampuran (Dokumen Pribadi)}

Setelah dilakukan uji susut pengeringan kedua bahan tersebut dicampurkan untuk dikemas kedalam kantung teh yang telah dipersiapkan.

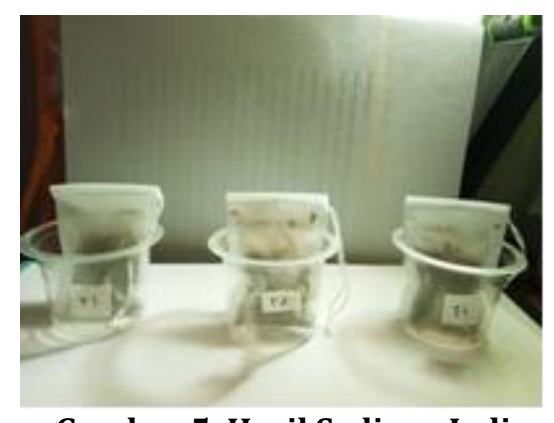

\section{Gambar 5. Hasil Sediaan Jadi}

Berdasarkan Gambar 5 menunjukkan hasil sediaan yang telah dicampurkan kemudian dikemas rapih menggunakan kantung teh.

\section{Uji Organoleptik}

Teh celup dari daun salam (Syzygium polyanthum) dan rimpang jahe merah (Zingiber officinale Rosc.Var.Rubrum) telah selesai dibuat lalu sediaan tersebut dilakukan pengujian organoleptik dengan mengamati bau, warna, bentu, dan rasa selama 3 minggu dengan pengamatan setiap 3 hari sekali disimpan dalam penyimpanan yang sama, yaitu dalam suhu ruangan 15$25^{\circ}$. Kemudian hasil pengamatan tersebut 
dicatat dalam bentuk Tabel 3 dan seterusnya.

Tabel 2. Hasil Uji Organoleptik 3 Hari Pertama

\begin{tabular}{|c|c|c|c|c|}
\hline \multirow{2}{*}{ Sampel } & \multirow{2}{*}{ Pengamatan } & \multicolumn{3}{|c|}{ Hari Ke- } \\
\cline { 2 - 5 } & Bau & Sedikit khas jahe & Sedikit khas jahe & Sedikit khas jahe \\
\hline \multirow{4}{*}{ F1 } & Warna & Hijau tua & Hijau tua & Hijau tua \\
\cline { 2 - 5 } & Bentuk & Serbuk kasar & Serbuk kasar & Serbuk kasar \\
\cline { 2 - 5 } & Rasa & Tidak terlalu hangat & Tidak terlalu hangat & Tidak terlalu hangat \\
\cline { 2 - 5 } & Bau & Khas jahe & Khas jahe & Khas jahe \\
\hline \multirow{4}{*}{ F2 } & Warna & Hijau tua & Hijau tua & Hijau tua \\
\cline { 2 - 5 } & Bentuk & Serbuk kasar & Serbuk kasar & Serbuk kasar \\
\cline { 2 - 5 } & Rasa & Hangat & Hangat & Hangat \\
\hline \multirow{4}{*}{ F3 } & Bau & Khas jahe lebih pekat & Khas jahe lebih pekat & Khas jahe lebih pekat \\
\cline { 2 - 5 } & Warna & Hijau tua & Hijau tua & Hijau tua \\
\cline { 2 - 5 } & Bentuk & Serbuk kasar & Serbuk kasar & Serbuk kasar \\
\cline { 2 - 5 } & Rasa & Hangat & Hangat & Hangat \\
\hline
\end{tabular}

Tabel 2 menunjukan bahwa pada tiga hari pertama, sediaan yang disimpan dalam suhu ruangan tidak menunjukan perubahan yang signifikan dalam hal bau, warna, bentuk dan rasa.

Tabel 3. Hasil Uji Organoleptik 3 Hari Kedua

\begin{tabular}{|c|c|c|c|c|}
\hline \multirow{2}{*}{ Sampel } & \multirow{2}{*}{ Pengamatan } & \multicolumn{3}{|c|}{ Hari Ke- } \\
\cline { 2 - 5 } & Bau & Sedikit khas jahe & Sedikit khas jahe & Sedikit khas jahe \\
\hline \multirow{4}{*}{ F1 } & Warna & Hijau tua & Hijau tua & Hijau tua \\
\cline { 2 - 5 } & Bentuk & Serbuk kasar & Serbuk kasar & Serbuk kasar \\
\cline { 2 - 5 } & Rasa & Tidak terlalu hangat & Tidak terlalu hangat & Tidak terlalu hangat \\
\cline { 2 - 5 } & Bau & Khas jahe & Khas jahe & Khas jahe \\
\cline { 2 - 5 } F2 & Warna & Hijau tua & Hijau tua & Hijau tua \\
\cline { 2 - 5 } & Bentuk & Serbuk kasar & Serbuk kasar & Serbuk kasar \\
\cline { 2 - 5 } & Rasa & Hangat & Hangat & Hangat \\
\hline \multirow{4}{*}{ F3 } & Bau & Khas jahe lebih pekat & Khas jahe lebih pekat & Khas jahe lebih pekat \\
\cline { 2 - 5 } & Warna & Hijau tua & Hijau tua & Hijau tua \\
\cline { 2 - 5 } & Bentuk & Serbuk kasar & Serbuk kasar & Serbuk kasar \\
\cline { 2 - 5 } & Rasa & Hangat & Hangat & Hangat \\
\hline
\end{tabular}

Tabel 3 menunjukan bahwa pada tiga hari kedua, sediaan yang disimpan dalam suhu ruangan tidak menunjukan perubahan yang signifikan dalam hal bau, warna, bentuk dan rasa.

Tabel 4. Hasil Uji Organoleptik 3 Hari Ketiga

\begin{tabular}{|c|c|c|c|}
\hline \multirow{2}{*}{ Sampel } & \multirow{2}{*}{ Pengamatan } & \multicolumn{2}{|c|}{ Hari Ke- } \\
\cline { 2 - 4 } & Bau & Sedikit khas jahe & Sedikit khas jahe \\
\cline { 2 - 4 } F1 & Warna & Hijau tua & Hijau tua \\
\cline { 2 - 4 } & Bentuk & Serbuk kasar & Serbuk kasar \\
\cline { 2 - 4 } & Rasa & Tidak terlalu hangat & Tidak terlalu hangat \\
\hline \multirow{4}{*}{ F2 } & Bau & Khas jahe & Khas jahe \\
\cline { 2 - 4 } & Warna & Hijau tua & Hijau tua \\
\cline { 2 - 4 } & Bentuk & Serbuk kasar & Serbuk kasar \\
\cline { 2 - 4 } & Rasa & Hangat & Hangat \\
\hline \multirow{2}{*}{ F3 } & Bau & Khas jahe lebih pekat & Khas jahe lebih pekat \\
\cline { 2 - 4 } & Warna & Hijau tua & Hijau tua \\
\hline
\end{tabular}




\begin{tabular}{|c|c|c|c|}
\hline & Bentuk & Serbuk kasar & Serbuk kasar \\
\cline { 2 - 4 } & Rasa & Hangat & Hangat \\
\hline
\end{tabular}

Tabel 4 menunjukan bahwa pada tiga hari ketiga, sediaan yang disimpan dalam suhu ruangan tidak menunjukan perubahan yang signifikan dalam hal bau, warna, bentuk dan rasa.

Berdasarkan pengujian organoleptik selama tiga minggu berturut-turut dapat disimpulkan bahwa dari Tabel $2-4$ menunjukan bahwa hasil pengujian organoleptik yang dilakukan peneliti dalam suhu ruangan $15-25^{\circ} \mathrm{C}$ tidak timbul perubahan yang signifikan dalam hal bau, warna, bentuk dan rasa. Hal ini terjadi diperkirakan karena dari proses pengambilan, dan penyiapan bahan baku serta sampai proses pembuatan yang teratur, maka dari itu tidak adanya perubahan negatif dalam sediaan yang dibuat.

\section{Hasil Uji Hasil Uji Kesukaan}

Tabel 5. Hasil Uji Kesukaan

\begin{tabular}{|c|c|c|c|c|}
\hline \multirow{2}{*}{ Jenis yang diuji } & \multirow{2}{*}{ Skor } & \multicolumn{3}{|c|}{ Kode Sampel } \\
\cline { 3 - 5 } & & F1 (\%) & F2 (\%) & F3 (\%) \\
\hline \multirow{2}{*}{ Aroma } & Tidak Suka & 66,67 & 13,34 & 3,33 \\
\cline { 2 - 5 } & Suka & 33,33 & 86,66 & 96,67 \\
\hline \multirow{2}{*}{ Rasa } & Tidak Suka & 53,33 & 3,33 & 3,33 \\
\cline { 2 - 5 } & Suka & 46,67 & 96,67 & 96,67 \\
\hline \multirow{2}{*}{ Warna } & Tidak Suka & 30 & 0 & 0 \\
\cline { 2 - 5 } & Suka & 70 & 100 & 100 \\
\hline
\end{tabular}

Adapun hasil penelitian ini didapatkan sediaan berupa teh celup yaitu sebagai berikut:

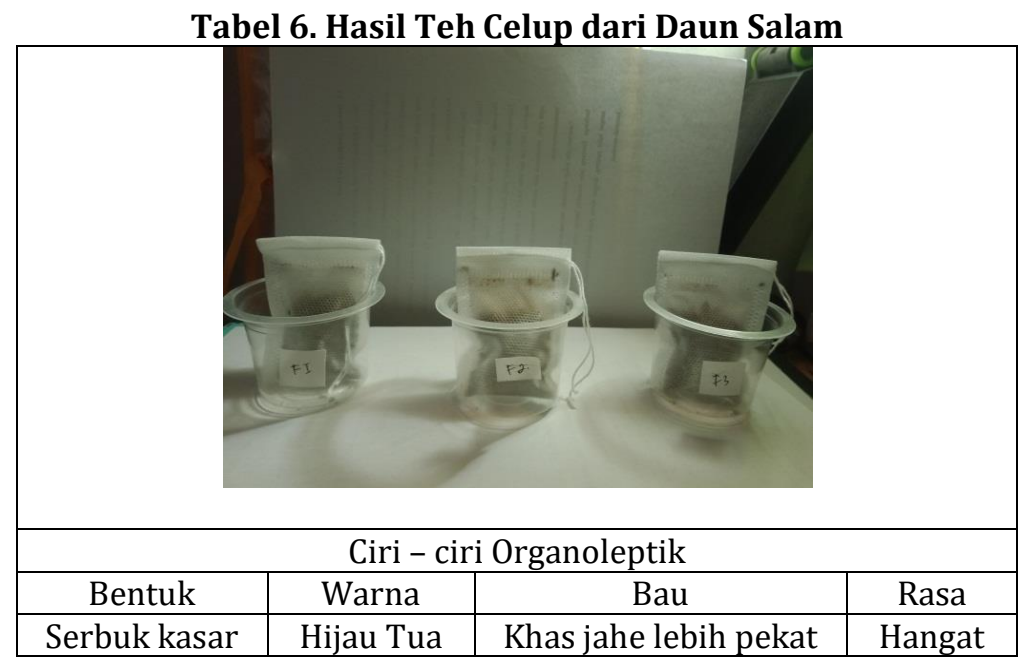

\section{PEMBAHASAN}

Berdasarkan pengamatan hasil wawancara yang tertera pada Tabel 1 diperoleh data terhadap 30 responden di Perum Jomin Estate Rt 004 Rw 009 Kec.Kotabaru Kab.Karawang. Pada hasil wawancara yang telah dilakukan, diperoleh data yang menyatakan bahwa dari 30 responden hanya 12 orang yang mengetahui penggunaan daun salam. Sebanyak 12 orang menyatakan pemakaiannya dapat menggunakan daun salam muda ataupun tua. Dalam penggunaannya, daun salam tersebut direbus ketika asam urat dengan tujuan untuk mengurangi rasa nyerinya sedangkan 
responden yang lain menyatakan belum mengetahui bahwa daun salam selain dapat dimanfaatkan sebagai bumbu dapur dapat juga digunakan untuk pengobatan tradisional khususnya untuk mengurangi kadar asam urat dikarenakan belum pernah mencoba pengobatan tradisional dan fungsi daun salam hanya sebagai penyedap masakan.

Berdasarkan data susut pengeringan yang diperoleh dari 2 sampel daun salam (A) dan jahe merah (B) menunjukan hasil presentase yang berbeda yaitu 3,2\% untuk sampel A dan 5\% untuk sampel B. Hasil susut pengeringan kedua sampel dinyatakan $\leq 10 \%$. Hasil susut pengeringan tersebut menunjukan bahwa bahan yang digunakan telah memenuhi persyaratan simplisia yang baik yaitu mengandung presentase kadar air $\leq 10 \%$ [11]. Susut Pengeringan dilakukan dengan tujuan untuk menghentikan aktifitas reaksi enzimatik yang dapat merusak simplisia tersebut [12].

Dapat dilihat dari hasil uji organoleptik sediaan yang telah dilakukan dan diamati selam 3 minggu tidak mengalami perubahan yang signifikan. Pada pengamatan hari ke-1 sampai dengan hari ke-21 ketiga sampel tersebut tidak menunjukan perubahan baik warna, aroma, bentuk dan rasa. Tidak terjadinya perubahan setelah uji organoleptik [9], hal ini menggambarkan bahwa kadar air sudah sesuai [12] dan menunjukkan bahwa sediaan teh celup stabil dalam penyimpanan selama 3 minggu.

Hasil pengamatan yang tertera pada Tabel 5 menunjukan hasil uji kesukaan 30 responden terhadap sediaan teh celup dari daun salam (Syzygium polyanthum) dan jahe merah (Zingiber officinale Rosc.Var.Rubrum). Dosis daun salam 1,25 gr, 2,5 gr dan 5,00 gr mampu menurunkan kadar asam urat, oleh karena itu peneliti menentukan dosis daun salam sebanyak 2,5 gr yang diambil dari rentang 1,25-5,00 gr [7]. Penentuan dosis yang efektif juga dilakukan dengan membuat formulasi jahe merah sebanyak 1 gram sebagai dosis awal untuk perasa alami dengan variasi pada formula 2 sebanyak 1,5 gr dan 2 gr pada formula 3. Formula 1 dengan komposisi daun salam 2,5 gr dan jahe merah 1 gr setelah diseduh menghasilkan aroma daun salam dengan sedikit aroma jahe merah, rasa yang tidak terlalu hangat dan warna yang tidak terlalu pekat. Formula 2 dengan komposisi daun salam 2,5 gr dan jahe merah 1,5 gr setelah diseduh menghasilkan aroma daun salam dan jahe merah, rasa yang hangat dan warna yang sedikit pekat sedangkan formula 3 setelah diseduh menghasilkan aroma khas jahe lebih pekat dengan sedikit aroma daun salam, rasa yang lebih hangat dan warna yang pekat. Dari hasil uji kesukaan diperoleh data bahwa dari segi aroma, rasa dan warna yang banyak disukai oleh masyarakat yaitu sampel formula 3 dengan komposisi daun salam sebanyak 2,5 gr dan jahe merah 2 gr. Hal ini dikarenakan jahe merah sebanyak 2 gr mampu menutupi rasa hambar yang dihasilkan oleh daun salam.

\section{SIMPULAN}

Berdasarkan hasil pengamatan dan analisis data yang dilakukan maka dapat disimpulkan bawah sediaan teh celup dibuat dengan metode pengovenan Sediaan teh celup dibuat dari daun salam dengan penambahan rimpang jahe merah sebagai perasa alami. Hasil susut pengeringan yang diperoleh dari 2 sampel menujukan 3,2\% untuk sampel A (Daun salam) dan 5\% untuk sampel B (Jahe merah), kadar air dalam daun salam dan jahe merah telah memenuhi persyaratan kadar air simplisia yaitu $\leq 10 \%$. Hasil uji organoleptik yang dilakukan pada ketiga formula tersebut tidak menunjukan perubahan yang signifikan. Perbedaan hanya terletak pada aroma daun salam yang khas dan rasa jahe merah yang khas saja. Perbedaan tersebut dipengaruhi oleh penambahan jahe merah pada setiap formulasi dengan jumlah yang berbeda-beda. Hasil uji kesukaan menunjukan bahwa formulasi yang banyak disukai yaitu formulasi yang banyak disukai oleh masyarakat yaitu formulasi 3 dengan komposisi daun salam 2,5 gram dan jahe merah 2 gram.

\section{DAFTAR PUSTAKA}


1. Jaliana, J., \& Suhadi, S. (2018). FaktorFaktor Yang Berhubungan Dengan Kejadian Asam Urat Pada Usia 20-44 Tahun Di RSUD Bahteramas Provinsi Sulawesi Tenggara Tahun 2017. Jurnal Ilmiah Mahasiswa Kesehatan Masyarakat, 3(2).

2. Krisnatuti. (2007). Perencanaan Menu Untuk Penderita Gangguan Asam Urat. Jakarta: Penebar swadaya.

3. Ramadani, A. (2018). Efektivitas Teh Herbal Daun Salam (Syzygium polyanthum WIGHT) Terhadap Penurunan Kadar Asam Urat Pada Mencit (Mus musculus). Jurnal Kesehatan, 3(1).

4. Andriani, A., \& Chaidir, R. (2016). Pengaruh Pemberian Air Rebusan Daun Salam (Syzygium Polyanthum) Terhadap Penurunan Kadar Asam Urat. Jurnal Ipteks Terapan, 10(2), 112-119.

5. Darussalam, M., \& Rukmi, D. K. (2016). Peran Air Rebusan Daun Salam (Syzgium Polyanthum) Dalam Menurunkan Kadar Asam Urat. Media Ilmu Kesehatan, 5(2), 83-91.

6. Lallo, S., Mirwan, M., Palino, A., Nursamsiar, N., \& Hardianti, B. (2018).Aktifitas Ekstrak Jahe Merah Dalam Menurunkan Asam Urat Pada Kelinci Serta Isolasi Dan Identifikasi Senyawa Bioaktifnya. Jurnal Fitofarmaka Indonesia, 5(1), 271278.94

7. Ariyanti, R., Wahyuningtyas, N., \& Wahyuni, A. S. (2007). Pengaruh Pemberian Infusa Daun Salam (Eugenia Polyantha Wight) terhadap Penurunan Kadar Asam Urat Darah Mencit Putih Jantan yang Diinduksi dengan Potasium Oksonat.
8. Palupi, M. R., \& Widyaningsih, T. D. (2014). Pembuatan Minuman Fungsional Liang Teh Daun Salam (Eugenia polyantha) Dengan Penambahan Filtrat Jahe Dan Filtrat Kayu Secang [In Press September 2015]. Jurnal Pangan dan Agroindustri, $3(4)$.

9. Novitasari, R. Ratnasari.,D., Nuraeni, S. (2018). Pembuatan Dan Uji Organoleptik Sediaan Teh Celup Daun Afrika (Vernonia amygdalina Del) Melalui Metode Pengovenan Dan Metode Sinar Matahari. Purwakarta. http://ejournal.stikesholistic.ac.id/jurn al.php?detail=jurnal\&file $=4 \% 20$ artikel \%20Reta\%20Novitasari.pdf\&id=579\&c $\mathrm{d}=0 \mathrm{~b} 2173 \mathrm{ff} 6 \mathrm{ad} 6 \mathrm{afb} 09 \mathrm{c} 95 \mathrm{f} 6 \mathrm{~d} 50001 \mathrm{df}$ $6 \&$ name $=4 \% 20$ artikel $\% 20$ Reta $\% 20 \mathrm{No}$ vitasari.pdf

10. Hart, E., \& Bond, M. (2000). Using action research. Using evidence in health and social care. London: Sage, 86-107.

11. Puspita, S., Yanto, E.S., Farhan. (2018). Pembuatan Sediaan Teh Celup Daun Saga (Abrus precatorius Linn) Dan Daun Sirih (Piper betle) Untuk Obat Kumur.http://ejournal.stikesholistic.ac. id/jurnal.php?detail=jurnal $\&$ file $=6 \% 20$ artikel\%20Sri\%20Puspita.pdf\&id=581 $\& \mathrm{~cd}=0 \mathrm{~b} 2173 \mathrm{ff} 6 \mathrm{ad} 6 \mathrm{a} 6 \mathrm{fb} 09 \mathrm{c} 95 \mathrm{f} 6 \mathrm{~d} 5000$ $1 \mathrm{df6} \&$ name $=6 \% 20$ artikel\%20Sri\%20P uspita.pdf

12. Departemen Keshatan Republik Indonesia, (2008). Farmakope Herbal Indonesia, 113-115, Departemen Kesehatan Republik Indonesia, Jakarta 